
IGNOTUM

\title{
ALCHEMY IN THE CONTEMPORARY WORLD - MAGNUM IGNOTUM
}

\section{АЛХИМИЯ В СОВРЕМЕННОМ МИРЕ - MAGNUM IGNOTUM}

\author{
VINOKUROV, Vladimir V.*; VORONTSOVA, Marina V. \\ Lomonosov Moscow State University \\ 11 Mochovaja str., 125009 Moscow, Russian Federation \\ * Corresponding author \\ ierosph@mail.ru
}

Received 12 June 2018; received in revised form 19 November 2018; accepted 23 November 2018

\section{RESUMO}

A alquimia na consciência moderna deixou de ser percebida como uma falácia científica que levou a uma massa de tentativas infrutíferas de obter a pedra filosofal, isto é, alguma substância através da qual se pode transformar chumbo em ouro. Nas obras modernas artísticas, filosóficas e psicológicas, a alquimia está presente como um fenômeno cuja essência é misteriosa e incompreensível, ou está perdida. A alquimia e a pedra filosofal hoje na sociedade são percebidas como Magnum ignotum (o Grande Desconhecido). Essa percepção deve-se, entre outras coisas, à diversidade de abordagens para estudar a alquimia e seus fenômenos. $O$ objetivo do artigo é apresentar a diversidade de abordagens historicamente desenvolvidas para o estudo da alquimia.O artigo tenta aplicar o método da fenomenologia da religião à alquimia. A fenomenologia enfatiza, antes de tudo, uma relação estrutural, e não histórica. O método fenomenológico de investigação encontra concretização na representação geométrica da estrutura da alquimia, que se correlaciona com a estrutura de investigação desse fenômeno.O artigo mostra que a diversidade de abordagens reflete a topologia especial do fenômeno da alquimia, que possibilita obter suas várias seções geométricas e considerá-las separadamente, mas nenhuma delas abrange o fenômeno da alquimia como um todo.Os materiais do artigo podem ser úteis para uma compreensão histórica dos motivos para o desenvolvimento da ciência.

Palavras-chave: estudos da alquimia, fenomenologia da alquimia, psicologia da alquimia, estrutura da alquimia.

\begin{abstract}
Alchemy in modern consciousness ceased to be perceived as a scientific fallacy which led to a mass of fruitless attempts to obtain the philosopher's stone, that is, some substance through which one can turn lead into gold. In modern artistic, philosophical and psychological works alchemy is present as a phenomenon the essence of which is mysterious and incomprehensible, or is lost. Alchemy and the philosopher's stone today in society are perceived as Magnum ignōtum (the Great Unknown). This perception is due, among other things, to the diversity of approaches to studying alchemy and its phenomena. The purpose of the article is to present the diversity of historically developed approaches to studying alchemy. The article attempts to apply the method of phenomenology of religion to alchemy. Phenomenology emphasizes, first of all, a structural relationship, rather than a historical one. The phenomenological method of investigation finds concretization in the geometric representation of the structure of alchemy, which correlates with the structure of the investigation of this phenomenon. The article shows that the diversity of approaches reflects the special topology of the phenomenon of alchemy, which makes it possible to obtain its various geometric sections and consider them separately, yet none of them embraces the phenomenon of alchemy as a whole. The materials of the article can be useful for a historical understanding of the motives for the development of science.
\end{abstract}

Keywords: studies of alchemy, phenomenology of alchemy, psychology of alchemy, structure of alchemy. 


\section{АННОТАЦИЯ}

Алхимия в современном сознании перестала восприниматься как научное заблуждение, которое вело к массе бесплодных попыток получить фрилософский камень, то есть какое-то вещество, при помощи которого можно превратить свинец в золото, и при помощи последнего обрести владычество над миром. В современных художественных, философских и психологических произведениях алхимия присутствует как феномен, сущность которого таинственна и непонятна, или же утрачена. Алхимия и философский камень сегодня в обществе воспринимается как Magnum ignōtum (Великое неизвестное). Это восприятие обусловлено в том числе и многообразием подходов к исследованию темы алхимии и ее феноменов. Цель статьи представить многообразие исторически сложившихся подходов исследования алхимии. В статье сделана попытка применения метода феноменологии религии к алхимии. Феноменология акцентирует, прежде всего, структурную связь, а не историческую. Конкретизацию феноменологический метод исследования находит в геометрическом представлении структуры алхимии, которое соотносится со структурой исследования этого явления. В статье показано, что все многообразие подходов отражает особую топологию феномена алхимии, позволяющую получать его различные геометрические сечения и рассматривать их отдельно, но ни одно из них не охватывает феномен алхимии в целом. Материалы статьи могут быть полезными для исторического понимания мотивов развития науки, к исследованию отношения науки и религии, когнитивных исследований.

Ключевые слова: эзотерические учения, исследования алхимии, феноменология алхимии, психология алхимии, структура алхимии.

\section{INTRODUCTION}

Accentuating the image of the alchemist and his search, modern literature offers an unusual twist of the story - the search is more important than the Stone, and what is meant by the Stone will be revealed only at the end of the search.

In the philosophy of the twentieth century, the alchemical theme continues in the works of René Guénon (1886-1951) (Guénon, 2004) and Julius Evola (1898-1974) (Evola, 1995). Ludwig Wittgenstein mentions the topic of alchemy in the 'Notes on the basics of mathematics' (1941/1944): "One can speak of a kind of alchemy in mathematics" (Wittgenstein et al., 1974, p. 274).

Alchemy plays a significant role in the deep psychology of C.G. Jung (1875-1961) (Jung, 1980) and his followers (Franz, 1980), in the religion and phenomenology of Mircea Eliade (1907-1986) (Eliade, 1991). It is possible to find certain parallels between alchemy and the religious and philosophical views of $P$. Teilhard de Chardin (1881-1955). Finally, in the modern world, there are alchemical schools and laboratories in which the students of the alchemists of the past and the present are trying to reproduce the Great Work and get at least a new generation medicine, if not the philosopher's stone itself.

Nowadays the topic of alchemy is widely represented in art and popular science fiction. Modern artistic and scientific-publicist literature attracts attention not so much to the philosopher's stone as to the protagonist searching for it, to the alchemist. In other words, modern prose emphasizes not the object of the Great Work but its subject. Alchemy and the philosopher's stone are present in the popular series of novels for children and young people by Joannne Rowling about Harry Potter, 'the boy who lived'. The first book, which brought the writer world fame, was devoted to hiding the philosopher's stone - the central object and purpose of alchemy - from the forces of evil. The alchemist, his formation, search and 'transmutation' is the subject of a series of alchemical novels by Gustav Meyrink (18681932). It must be said that the work of Meyrink stands out among other works on the topic. The very sequence of novels reproduces the order of the operations of the Great Work: nigredo $\rightarrow$ albedo $\rightarrow$ rubedo (black, white, red).

The historical prototypes of the characters of most of the works of art are some ancient magicians and alchemists (more precisely, their images and legends about them) who received 
their mastery from the Egyptian god of magic Thoth. These are the alchemists of the Middle Ages: Ramon Llull (1232-1316) and Nicolas Flamel (1330-1418), scientist, doctor and magician of the Renaissance Paracelsus (Theophrastus Bombast von Hohenheim (Paragranum, Paramirum, 1493-1541)), and alchemist and clairvoyant of the Elizabethan era Edward Kelly (1555-1597). The most famous characters of the XVIII century are Count SaintGermain (1710-1784) and Count Alessandro di Cagliostro (Giuseppe Balsamo (1743-1795); it is noteworthy that the images of the latter against the backdrop of the successes of the natural sciences acquire the features of wickedness.

Alchemy in modern consciousness ceased to be perceived as a scientific fallacy which led to a mass of fruitless attempts to obtain the philosopher's stone, that is, some substance through which one can turn lead into gold and with the help of the latter gain dominion over the world. In all the above works, alchemy is present as a phenomenon the essence of which is mysterious and incomprehensible or is lost. Alchemy and the Philosopher's Stone today in society is perceived as Magnum ignōtum (the Great Unknown).

\section{METHODOLOGICAL FRAMEWORK}

The topic of alchemy in the history of culture and religion and its significance in the modern world, as already shown above, attracted the attention of representatives of various fields of knowledge. As a result of this work, different approaches were formed, and each achieved significant results. Each direction creates an image of alchemy from its own point of view, from its own perspective. Together they form a class of studies of the alchemical tradition and, accordingly, can be classified and partly structured on the basis of their approach. The research further on is presented within the framework of the 'approach-object' double coordinate system. Therefore, any study is presented as a function of $f(x, y)$. Thus, understanding what the philosopher's stone is and the elixir of immortality depends on what practice one calls alchemy. All the approaches see their subject as a projective image, that is, from a certain point of view. 'The Philosopher's Stone' is a phenomenon including an imaginary component that completes 'what we see' up to 'what we understand'.

\section{LITERATURE REVIEW}

At present, several academic approaches to the study of alchemy emerged in Western religious studies. First of all, in these works, studies of alchemy are placed in the circle of studies of 'esotericism'. Second, the question of studying alchemy shifts to the question of classifying academic research (whether the study is scientific or unscientific), and of classifying researchers (scientists or esotericists). This definition was investigated in the works of the Amsterdam religious scholar Wouter J. Hanegraaff (2013).

In the studies of Western esotericism, Hanegraaff identifies several models:

the first model contrasts the natural philosophy of the early Modern Age with rationalism and science (Antoine Faivre, Frances Yates);

the second '(post) modernist' model views 'occultism' as a strange phenomenon of modern culture, blurring the contradiction between the imagined and the real;

the third - the model of the 'hidden tradition', is most often characterized as 'religionism', it is possible to search for truth not only by scientific methods (Mircea Eliade, Carl Jung, Henri Corbin, Arthur Versluis), for example, depth psychology (Hanegraaff, 2013, p. 11 - 12).

The application of the concept of Hanegraaf, its verification and the historiography of authors and works corresponding to different models was undertaken by Nosachev (2015). He notes that the concept of Hanegraaff was continued in the works of Steven M. Wasserstrom (1999) and Kocku Von Stuckrad (2009), which introduces the clarification of the term 'religionism' with the help of the term 'mystocentrism', according to which the essence of religion should be found in a mystical experience (Nosachev, 2015).

Steven Wasserstom, Kocku Von Stuckrad and Pavel Nosachev (Nosachev, 2015, pp. 2528; Stuckrad, 2009, p. 46; Wasserstrom, 1999, p. 234) include Gershom Scholem, Henri Corbin, Mircea Eliade, Martin Buber and Carl Gustav Jung in the 'mystocentrism', uniting them in the so-called Eranos Circle. The question is how critical the unification of their views is because such combination of views erases the boundary between religion and its study, between 
psychology, culture, and mysticism.

Jung in his letter to Robert C. Smith, on June 29, 1960, noted the following:

"Buber and I start from an entirely different basis: I make no transcendental statements. I am essentially empirical, as I have stated more than once. I am dealing with psychic phenomena and not with metaphysical assertions. Within the frame of psychic events, I find the fact of the belief in God. It says: "God is." This is the fact I am concerned with. I am not concerned with the truth or untruth of God's existence. I am concerned with the statement only, and I am interested in its structure and behavior. It is an emotionally 'toned' complex like the father or mother-complex or the Oedipus complex. It is obvious that if a man does not exist, no such statement can exist either, nor can anybody prove that the statement 'God' exists in a nonhuman sphere. $\langle\ldots\rangle$ How does Buber know of something he cannot 'experience psychologically'? How is such a thing possible at all? If not in the psyche, then where else? You see, it is always the same matter: the complete misunderstanding of the psychological argument: 'God' within the frame of psychology is an autonomous complex, a dynamic image, and that is all psychology is ever able to state" (Jung et al., 1990, pp. 570-572).

Jung defined his position as psychological empiricism but in no way as 'mystocentrism'. Psychological empiricism establishes an obstacle on the path of 'mystocentrism'. In the quoted letter of Jung there is an additional explanation of his position: "If Niels Bohr compares the model of the atomic structure with a planetary system, he knows it is merely a model of a transcendent and unknown reality, and if I talk of the God-image I do not deny a transcendental reality. I merely insist on the psychic reality of the God-complex or the God-image, as Niels Bohr proposes the analogy of a planetary system. He would not be as dumb as to believe that his model is an exact and true replica of the atom. <> Buber criticizes me in a field in which he is incompetent and which he does not even understand" (Jung et al., 1990, pp. $572-573$ ).

In this letter, Jung admits a conjunction in relation to his statements with the transcendental reality ' $p \wedge \sim p$ ', nevertheless, he does not allow contradiction in the field of psychology, since he does not at all relate his statements to the transcendental reality itself and does not solve the question of the truth of his statements in the transcendental area. With respect to the transcendental reality, Jung's statements are not a contradiction but a tautology, that is, they do not say anything about it. While the use of the terms 'religionism' and 'mystocentrism' implicitly relates it to the reality of religion or mysticism.

In the antiphenomenological approach, there is a contradiction: that which is a psychological fact for Jung is uncritically projected into reality, while the question under what conditions this is possible remains unresolved.

\section{RESULTS}

With regard to alchemy, the question arises: how psychological reality could be projected into actual reality, how could psychology appear as chemistry? This is possible if the world of psychological phenomena has something in common with the real world. This formulation of the question requires the unification of the second and third models of alchemic research since the contradiction is removed by introducing the concept of 'possible world'. The 'possible world' is simultaneously an 'imaginary world'. The difference between these worlds is not revealed a priori but only when they are compared with reality. The presence of alchemic texts, sentences and formulas does not mean the presence of the philosopher's stone. However, this state of affairs requires the projection of proposals for reactions. Reading the alchemic text, we understand only what is projected but not what was projected. To understand what was projected means to understand the meaning of the alchemic propositions, i.e., to answer the question which an alchemist is. This approach requires consideration of the projections of alchemy which are presented in the historically developed concepts of this phenomenon.

\section{DISCUSSION}

Alchemy, like any other esoteric discipline, is oriented towards 'tradition', and the latter can be understood widely, including myths, superstitions, legends, parables, etc. Thus, Paracelsus, collecting legends, learned from 'ignorant' healers and fortune-tellers and claimed 
that they were much more significant for his medical research than contemporary 'scientific' works. Paracelsus described this difference with the help of the terms experiment and experience, which includes an understanding of the things in themselves (Paracelsus, 1993, pp. 68-74). Science is based on experiment, and folk tradition on experience, on the knowledge inherent in plants, animals and man, on a person's ability to understand those. In accordance with the esoteric tradition, the task of science is not to be separated from the ancient beliefs, but, on the contrary, to be united with them, as it once was, while the esotericists refer to the Sumerian collection of medical prescriptions deciphered in 1955 (2200- 2100 BC) (Folta and Novy, 1987, p. 29), as well as to the Egyptian medical papyrus (Ebers Papyrus circa $1500 \mathrm{BC}$ ), in which "magical and rational medical prescriptions are given together" (Smirnova, 2004, p. 5).

In the Middle Ages and up to the Modern Age, alchemy was part of the body of 'sciences' and doctrines which were called Hermetic, named after the Greek god Hermes, attributed to the art of divination (here: foresight) and the art of interpreting the will of the gods (hermeneutics). Functionally, Greek Hermes corresponded to Egyptian Thoth, the master of the art of magic, the hidden 'words of power', the utterance of which engendered an irresistible action in the world around him. The place of the Hermetic complex and approach is between scientific and philosophical knowledge, and, on the other hand, magical and mythological relations to the world and man. Hermetic thought is addressed both to the past, to myth and magic, and to the present, as it attentively regards modern achievements of science and philosophy. Marcelin Berthelot, studying alchemy, generalizes this point of view in relation to the subject of interest, noting that alchemy is on the verge of magic and science, being a transitional stage between them.

The Hermetic doctrine of alchemy was based on the postulate of the Emerald Tablet by Hermes Trismegistus: "What is below is like that above, and that which is above, is like the one below. And all this only in order to accomplish the miracle of one" (Ruska, 1926). Here, the originally ambivalent elements 'top', 'there-here', 'beginning-end', are brought into correspondence through similarity and then unite into one. 'Here' and 'below' are the beginning, 'there' and 'above' are the end, and 'above' is the beginning of the changes 'below'.
In other words, the Hermetic doctrine is closed and the conclusion follows: a change in the bottom will cause a change at the top and a change at the top will cause a change at the bottom. There is an infinite chain of mutually closed changes. When the beginning and the end are united, the result is the circle that lies at the base of the Hermetic (esoteric) teachings. The basis of the unity of the 'top' and the 'bottom' is the similarity, and the principle of similarity is underlying for the imitative magic: similar affects similar, generates similar, is dissolved in similar, is killed by similar, and is cured by similar.

Any tradition at a certain level of development, in order to take the next step, turns to the study of itself, realizing the reflection of its sources, bases, concepts, and methods. This approach is denoted by the word 'traditional'. For the present study this group of materials, on the one hand, acts as sources, on the other hand, as research, that is, the study of esoteric teachings is undertaken in them with the aim of continuing the tradition, often through interpretation and reinterpretation of their concepts and principles. The research side, of course, is not present in all works, yet it already occurs with ancient and medieval thinkers. Plato's dialogues 'Phaedrus' (Plato, 1989, pp. 65-66: 274, c-d) and 'Philebus' (355 BC) contain an interpretation of the image of the Egyptian god Thoth, and already Plato transforms his image into a legend, the elements of which will firmly enter the esoteric constructions where he is considered the founder of the collegium of the priests of Ancient Egypt, who initiated the Hermetic tradition. Plutarch gives the Greek interpretation of the myth of Isis and Osiris, providing important information for this topic, but at the same time intertwines it with Greek mythology.

In the Middle Ages, during the Renaissance and the Modern Age, the interpretation of the sources and foundations of the Hermetic tradition was continued in attempts to interpret Hermetic texts through Egyptian and Greek mythology and through the ancient Egyptian hieroglyphic writing. The understanding of the practice of alchemy is found in the works of Albertus Magnus (1193$1280)$ and Basilius Valentinus (XVI century). The alchemical interpretation of Egyptian and Greek mythology is presented in the works of Dom Antoine-Joseph Pernety (1716-1802).

The traditional works on the alchemy of the XX century include Fulcanelli, \& Sworder, 1984; Fulcanelli, 1999, Baulot, Canseliet, \& Flouret, 
2005; Canseliet, 2010 , D'Ygé, 1954); the works by Butuzov (Butuzov, 2006) also adjoin to the traditional approach.

The second trend of traditional alchemy is rather connected with the search for an 'elixir of immortality' and focuses on the preparation of tinctures which have therapeutic and curative effects. Such tinctures and elixirs were prepared by Paracelsus, becoming the founder of iatrochemistry (from the Greek iātralīptēs - a doctor doing the inunction).

Currently, schools related to this area of alchemy exist in the United States, lead by Frater Albertus Spagyricus (Albert Riedel), head of the Paracelsus Research Society. Albus Zelator gives a collection of recipes and methods of preparation in his book. This trend of alchemy is developing in Russia as well - in Dagestan, Makhachkala the society 'Avicenna' operates at the Caucasian Secular Institute, which "... on the basis of ancient recipes invented a balm (an ointment), which should be rubbed onto the body. Penetrating through the pores, it opens them, speeding up the revival, that's why it is called 'Reviver'. 'This balm', say the authors 'we tested on injured athletes, and it was highly appreciated. Let them not suspect us of dirty commerce, so widespread now. Making a balm is very laborious and expensive; in time, we will present it to the poor for free" (Magomedov et al., 2009, p. 47).

The traditionalist approach is represented by the works of R. Guénon and J. Evola. "Alchemy is an art invented by alchemists," said Albertus Magnus (1980, p. 350). Therefore, first one needs to look for an alchemist dedicated to the Tradition of Alchemy, and then for the philosopher's stone. Traditionalists try to carry out by means of philosophy the authentic reconstruction of the Great Work, to understand it as it was understood by the alchemists, thereby uncovering the 'secret of alchemy'. From the point of view of the traditionalist approach, the philosopher's stone exists, although it is not very clear what it is, it should be sought in the unity of the subject and object, that is, there is a subjective component in the alchemic work. In other words, to get the Stone, you need a true Alchemist; if there is no alchemist, there is no stone.

The enlightenment approach in the field of alchemy is evident in the works of the medieval scholar Georgius Agricola (1494-1555), in the writings of the French enlighteners of the XVIII century Voltaire and Diderot, Ernst Mayr, N.A.
Figurovsky. The Enlighteners considered alchemy, astrology, magic the result of the delusion of some and the deception of others. This approach remains quite popular today, although it does not agree with the scientific study of Hermetic phenomena. From the point of view of modern research, a part of the historical phenomenon here stands out for the whole: pars pro toto (i.e., there is a logical error: 'Part instead of the whole'). In any case, the enlightenment approach is far from indiscriminate criticism and relies on common sense and natural science.

The scientific-educational approach, combining the educational point of view with the scientific criticism of the educational approach, was formed, oddly enough, in the study of alchemy (it would seem that astrology is closer to this intention), and views the latter as a stage in the development of chemistry. It is this approach which combined the ideas of the Enlightenment with natural science and its history and became the basis for the formation of a classical view of the Hermetic tradition. It was revealed in the writings of R. Boyle, M.S. Khotynsky, M. Berthelot, M. Giua. This approach is based on the reality of the object of alchemy, proving that it is indeed real and that behind the curtain of illusions and allegories lies the 'solid body' of chemical transformations and very unusual experiments of physics. The authors do not reject the fraud of magic, but in a number of cases see deeper grounds for occult phenomena.

In this connection, the position of the founder of chemistry Robert Boyle is typically characteristic. He tried to carry out an alchemically inverse transmutation, that is, not to turn lead into gold but, on the contrary, gold into lead. Naturally, such operation could not bring financial dividends in the form of gold bars and the resulting wealth. From a financial point of view, this enterprise is useless. The value of the reverse 'transmutation' for science and for the scientist blocked the meaning of wealth, but the nature of metals could neither be improved nor worsened.

The works of this direction in the study of magic reveal that a number of cases referred to as 'magic miracles' are not a question of conscious fraud and deception, but of sensory illusions and the use of unusual phenomena created by the laws of acoustics and optics, that is, in fact, about the experimental comprehension of these phenomena. One hardly dub a charlatan the person mastering the possibility of focusing 
the sound signal in a place different from its actual source ('ventriloquism'), and at the very best have an extremely vague idea of the laws of acoustics, if none at all. This person would find themselves (if such an experience occurs spontaneously) that someone else, invisible and unknown, spoke to them. It is equally difficult to imagine that one can lower your hand into molten iron and remove it unscathed, and yet such trick had a rigorous scientific basis and was well studied in the 19th century (Khotinsky, 1866, p. 254).

This approach is focused on desacralizing the content of ancient and medieval 'dark' texts, to identify in them a scientific component and reformulate in modern scientific language the problems they solve. Rational and scientific components of alchemy are considered from the point of view of the history of thermodynamics in a collective monograph devoted to the history of teachings on chemical processes, where it is shown that the basis for a number of alchemic experiments is the absolutely correct scientific idea of the thermodynamic effect of a chemical reaction (History ..., 1981).

One can give a 'thermodynamic' interpretation of the following alchemical fragment. Describing the stages of the Great Work, alchemists widely use metaphors, legends and various forms of allegory. XVI-XVII century alchemist Michael Maier in 'Atalanta fugiens' (1618) characterizes the first stage - nigredo - by the following allegory: "Put (a cold - V.V.) toad on a woman's breast so that she fed it; the woman will perish, but the toad will grow mighty" (Maier, 2004 , p. 69). The alchemists knew that thermal effects almost always accompany chemical changes, so the absorbed heat of the woman must make some 'chemical' changes in the toad's body, as the toad remains cold until all the warmth of the woman has passed to it. The reaction in the toad's body means a chemical reaction that takes place in a closed vessel with heat absorption, which, as it were, is condensed, is collected inside the vessel, from the outside it passes inwards. This is how the Philosophical Sulfur is formed, from which they prepare the Elixir. If the frog's body does not heat up, and the heat continues to be absorbed, it means there is chemical or biochemical synthesis inside it.

The scientific-historical approach represents the development of the scientific-educational approach, supplementing it with archaeological and textual research.
The educational-hypothetical approach is a complex synthetic inversion of the scientifichistorical and educational approaches. It is formed, on the one hand, holding an educational setting with regard to the problem of Hermetic teachings, and on the other hand, as a hypercritical attitude towards the Enlightenment. Thus, its authors seek enlightenment, pointing out a problem that stayed out of the sight of science, and even seek to expose the incorrect actions of scientists, charging them with bias in the analysis and selectivity of materials, and at the same time, they speak of the 'dark core' of Hermetic teachings which was formed in the depths of history and manifested in social and individual psychology. This is the 'shadow of the Enlightenment'. This approach is close to psychoanalysis in relation to the subject of science, i.e., community of scientists, and first of all, historians.

Science, bringing the enlightenment to its logical conclusion, allowed noticing this 'indivisible nucleus', the 'shadow' that disappears whenever science explores its object or whenever there are attempts to grasp it with the help of scientific methods, but at the same time, it finds, covers and captures new areas of knowledge, lives in the secrets of history and social psychology, in the depths of the individual and collective psyche. In studies of esoteric disciplines, it manifests itself as an unexpected hypothesis, requiring it to be included in the structure of scientific research. The works undertaken in this direction include the works of Weidner and Bridges (Weidner et al., 2003), R. Bauval and A. Gilbert (1994), M. Baigent and R. Leigh (2005). A clear artistic illustration of the application of this approach is Dan Brown's bestsellers.

The natural-scientific approach develops, first of all, in the context of scientific revolutions of the 17th and 20th centuries. The attitude of modern physicists and chemists toward alchemy can be characterized as 'cautious'. Transmutation involves nuclear transformations, yet the alchemists did not know anything about the structure of the atomic nucleus, did not have modern equipment and were unable to carry out nuclear transformations and release the nuclear energy necessary for the transmutation of metals. Their practice was contrary to the experimental method of successive operations which presupposes a controlled change in at least one of the factors. The alchemist repeats the same operation endlessly, changing nothing in it, his 
actions are compared with the process of washing clothes with the art of 'washerwomen' which was expressed in the title of the main work of Nicolas Flamel - 'The Book of Washing'. Thus, the alchemist deals, from the point of view of scientific enlightenment, with a senseless thing. However, it turns out it is not quite so, from the point of view of the 'natural history of man' by $L$. Wittgenstein (Wittgenstein et al., 1974, p. 92).

L. Wittgenstein characterizes the process of obtaining an infinite series as 'mathematical alchemy' where the mathematician repeats the same operation to obtain an infinite series. After all, we do not know an infinite series, but we know the operation of obtaining it. However, if it is a question of obtaining the approximation of the number ' $\pi$ ', it is necessary each time to reconstruct the cross-sections of the areas of inscribed and circumscribed circles.

The classical approach to alchemy is formed on the basis of educational, scientific and historical approaches, but is complemented by the philosophical idea of the objective development of religion, history, society, and science. It is formed under the influence of German classical philosophy of the XIX century, primarily the works of G.W.F. Hegel. Hermetic doctrines here appear as a stage of an objective process which is cognition of nature and society, the gradual formation of rational (logicaldiscursive) thinking and scientific research of nature and society, the liberation of cognition and human activity from magical, religious, mystical and ritual-symbolic components. Alchemic teachings and practices act as a whole, in which the intertwined and interacting magic, religion, science, and art, not yet separated from each other, form the 'sacral-cognitive complexes'. From this point of view, progress in one area of the complex should lead either to the evolution of representations in other areas of the whole or to the displacement of its constituents to the periphery and liberation from them. This approach is implemented in historical studies, supported by philosophical and religious studies and ideas.

With the implementation of the classical approach in the study of alchemy, the latter demonstrated greater flexibility. What was discarded by science in the study of alchemy and astrology proved to be viable and found other applications. This suggested that either there is an undefined, and possibly indivisible, integrity within alchemy, or the 'remains' of alchemy that have not found the interpretation in chemical processes (lions, dragons, eagles, hermaphrodites, etc.) retain their significance and can be meaningfully used, having a different field of application than the chemical process. Psychology became this area thanks to the work of Jung.

The psychological interpretation of C.G. Jung occupies a special chapter in the historiography of alchemy. At present, the works of Jung on alchemy is usually classified into those that constitute the 'small alchemic cycle', and those that form the 'great alchemical cycle'. The former includes works which compile the corpus 'Alchemical studies' (Jung, 1990); the latter includes 'Psychology and alchemy', 'Mysterium Coniunctionis', 'Aion'. Studies of alchemy in a psychoanalytic manner are continued in the works of disciples and followers of Jung (Mathers, 2014). According to Jung, a true understanding of alchemy can be achieved, first of all, if one abandons its chemical interpretation. If one just once asked whether the chemical intention of alchemy was genuine, that is, whether the adepts of the royal art were true chemists or simply using chemical jargon, then the texts themselves would eloquently suggest the need to consider alchemy from a different angle, from a purely chemical interpretation of it" (Jung, 1990, pp. 204-205). Taken with respect to esotericism and alchemy, Jung's statements about psychology ('p') take the form of disjunction "pv q' ('q' - chemistry), where the class of utterances ' $p$ ' which includes part of the statements from the class of utterances ' $q$ ' ("it is impossible to obtain the philosopher's stone by chemical methods") will be common. Then, under the philosophical stone one can consistently understand something relating to psychology, to the class of ' $p$ ' utterances. In other words, the philosopher's stone was searched not in the place where it exists; and it exists in the minds of alchemists - this is a fact.

Jung's approach emphasizes the subjective component, understanding it as a component of the psychological. The latter, in turn, is represented by the individual and collective properties of the subject, within which the archetypal ones are distinguished, which represent the object within the subject. The subject of alchemic doing 'The Spirit Mercurius' in the eponymous work of Jung is regarded as a spirit enclosed in an artificial body - a bottle, and this foreign body is incorporated into the human psyche and for the time being is undetected and 
unknown there (Jung, 1990, pp. 193-203).

The prerequisites of his concept Jung saw in the imaginative approach to the search for the philosopher's stone in alchemy. An approach linking the activity of the imagination with the search for the philosopher's stone or the elixir of immortality was formed by Paracelsus. Alchemy, according to this point of view, is based on the ability of the imagination.

One of the names of the philosopher's stone is 'projection powder'. At a certain stage of alchemy, the adept must project a substance in a hermetic vessel, an image from the depths of his imagination and memory. Paracelsus paid attention to the fact that the imagination penetrates the body; thus, the pictures of the imagination of the future mother influence the child: "As in vitriolo (here: copper), the imaginary (imprinted) is imprinted (minted) with the help of imagination. This is the imprint of the light of nature (luminis naturae), and there are rays (radiance), which are imprinted in you, imprinted with the power of imagination" (Paracelsus, 1993, pp. 74). True, imagination should be distinguished from fantasy; in the latter case, imagination is subject to reason. Imagination by Paracelsus is the power of the soul produced by active consciousness and will.

The magical-erotic and sensual aspects of the imaginative approach to alchemy are presented on the basis of work with the documents of the 'Golden Dawn' by Israel Regardie. Israel Regardie (1907-1985) is an authority in the field of magic and Hermeticism, continuing the tradition of the 'Golden Dawn', regarded alchemy as "a secret form of practical magic" (Regardie et al., 2010, p. 369). If Jung considered magic as psychology, then the magical-psychological approach of Israel Regardie is aimed at solving the directly opposite problem, it presents psychology as modern magic, thereby regressing into the past and gross.

Regardie notes, based on the work of alchemists and Hermeticists that alchemy uses two magic tools, namely, a round crystal vessel (retort) and a furnace (alchemic Atanor); the former represents the female aspect of sexuality, the second represents the male aspect. In obtaining 'gold', two substances participate, one of which is male, the other female, "... they are called: Serpent, or Blood of the Red Lion, and Tears, or Gluten of the White Eagle. <...>. These two substances are, in fact, the products of Lion and Eagle" (Regardie et al., 2010, p. 374).

The unification of the male and female as the 'alchemic marriage of the Moon and the Sun' should lead to 'alchemical gold' or the Dew of Immortality, which is used in further magical operations of ritual and talismanic magic. "The supreme power acting in this technique is love ... The power of love directed by Will and guided by the Soul" (Regardie et al., 2010, p. 376). Regardie pays special attention to the theurgical aspect of the whole operation, namely, the utterance of divine names and prayer: "All the authorities in the field of alchemy who have considered this method agree on a single opinion - it is unique in its essence and gives amazing results, but only in combination with prayers. It turns out that during the operation or mass, while the flame is burning in the Atanor, the theurgist should tirelessly pray, that is, either mentally or read the spells aloud" (Regardie et al., 2010, p. 378).

In the 'Golden Dawn' reincarnation of alchemical ideas started in the context of a wide range of Hermetic, kabbalistic and esoteric texts, which leads to the transfer of the alchemic operation from the world of the chemical laboratory to the sphere of sexual ritual magic (Kraig, 2011).

\section{CONCLUSIONS:}

The phenomenological approach makes it possible to single out, as an object of study, the legend of the alchemist and the philosopher's stone. The legend is related to myth, yet it is not formed around gods and their actions but around the historical core, the historical personality. It is akin to an alchemic reaction, in which there is a chemical basis, yet this historical core is surrounded by a 'nebula'.

Dealing with the legend, there is a great temptation to assume that the protagonist, from the point of view of history, is a collective character, that is, the same legend incorporates various historical figures, it 'roams' through history and geography. However, between the characters and their stories, the legend establishes symmetry and correlation, forming structural connections. This is similar to the difference between the physical and mathematical points that lie on the time and space line. From the standpoint of mathematics, 
each point of the space-time continuum is different from the other, from the standpoint of physics, this is not possible. The paradox is that if one admits the actual width of a point or the length of a segment, then the width and length (physical quantities) can exist only if the close points are indistinguishable. If Point $A$ can be distinguished from Point $C(A<C)$, but Point $B$ cannot be distinguished from either Point $A(A=$ $B)$ or Point $C(B=C)$, then this relation will make Points $A$ and $C$ non-distinguishable. The initial inequality turns into an equation:

$$
A<C \cdot A=B \cdot B=C \therefore A=C \text {. }
$$

The legend makes historical and mythological characters indistinguishable and unites them into one. Historical research is aimed at distinguishing all the points, and the more subtle instruments are used, the more points will be found on the line. Consequently, this side of the problem is connected with the problem of measurement and therefore, assumes that we are dealing with the metric space of history. Yet along with the paradox of a physical point, there is the paradox of a mathematical point located on a series. It arises as a result of dividing a straight line by a circle. The circle divides the points ' $X=$ $\mathrm{k} \sqrt{ } 2$ ' into two classes: upper and lower. A measurement attempt will lead to it alternately appearing in one class, then in the other. The break point will slip away and is always between the upper and lower classes, history and myth. It will be a 'flickering' concept (L. Wittgenstein), appearing here and there. This means that in the history of man the real and imaginary events form symmetrical structures. In this one can see the essence of the phenomenon of alchemy.

The most important here is the notion of a 'section' of Dedekind s theorem. The section is a key concept of topology and topological models; it is fully adapted in the classical phenomenology of religion and esoteric teachings. Here it is important to show its application in studies of alchemy. The scientific and educational approach cut alchemy, separating the chemical component from it, discarding the rest. It is possible to determine the chemical content of alchemy as the lower class in the cross section. Yet the traditional and culturological models stood firmly, insisting on the integrity of this phenomenon. Quite unexpectedly, Jung conducted a different section of alchemy, singling out the deeppsychological content of the phenomenon, discarding the chemical content.

From the point of view of topology, the phenomenon of alchemy has a very strange configuration, which involves two closed curves to obtain a section of its surface. As Henri Poincare demonstrated, this is the definition of the surface of the Riemann torus. The sphere does not satisfy this condition; thus, the psychological and chemical aspects are projective images of one phenomenon. It 'flickers', passing from one class to the other without being damaged. The most important symbol of the elixir of immortality - Uroboros (a snake biting its tail) - is a graphic illustration of the geometric figure of the torus.

\section{RECOMMENDATIONS}

The materials and conclusions of the paper are of interest for historians of science, philosophers dealing with problems of science and religion, psychologists and religious scholars, and can also be used in psychotherapy.

\section{REFERENCES:}

1. Aguilar, J. C.; Rodrıguez, E. G.; Vaccine adjuvants revisited; Vaccine 2007, 25, 372.

2. Albertus Magnus; Libellus de Alchimia, Nauka: Moscow, 1980.

3. Ananich, I. V.; Derkho, M. A.; Kontsevaya, S. Y.; Biochemical indices of rats' blood. Veterinarnaya Klinika 2008, 10, 35.

4. Baigent, M.; Leigh, R.; The elixir and the stone, Random House Canada, 2005.

5. Basilius Valentinus; Alchemical treatises, Avtograf, 2008.

6. Baulot, I.; Canseliet, E.; Flouret, J.; Lalchimie et son "Livre muet": Mutus liber, Gutenberg reprints: Paris, 2005.

7. Butuzov, G.; Alchemy and tradition: Articles of 2000-2005; V.G.: Moscow, 2006.

8. Canseliet, E.; Nouvelles études diverses de symbolisme hermétique et de pratique philosophale, G. Trédaniel: Paris, 2010.

9. Chernikova, M. I.; Kashirina, O. S.; Vasiliev, Y. M.; Comparative study of immunogenicity of adjuvants of different nature and action mechanism on the model of inactivated flu vaccine; Zhurnal 
Mikrobiologii, Epidemiologii i Immunologii 2015, 6, 63.

10. D'ygé, C.; Nouvelle Assemblée des Philosophes Chymiques. Aperçus sur le Grand-Oeuvres des Alchimistes. Préface de Eugène Canseliet, Dervy-Livres: Paris, 1954.

11. Edelman, R.; Vaccine Adjuvants; Rev. Infect. Dis. 1980, 2, 383.

12. Eliade, M.; Alchimia asiatica, Humanitas: Romana, 1991.

13. Evola, J.; The Hermetic Tradition. Symbols \& Teachings of the Royal Art, Inner Traditions International: Rochester, VT, 1995.

14. Folta, Ya.; Novy, L.; Natural History in dates, Progress: Moscow, 1987.

15. Franz, Marie-Louise von; Alchemy: An Introduction to the Symbolism and the Psychology Studies in Jungian Psychology, Inner City Books: Toronto, 1980.

16. Fulcanelli; Alchemy. Christian art and symbolism. Architecture, Medieval, Archive Press and Communications: Boulder, CO, 1999.

17. Fulcanelli; Sworder, M.; Fulcanelli; Master alchemist: Le Mystère des Cathédrales, Esoteric interpretation of the hermetic symbols of the great work, Brotherhood of Life: Las Vegas, NV, 1984.

18. Gilbert, A.; Cook, R.; Orion mystery unlocking the secrets of the pyramids, Arrow Books, 1994.

19. Hanegraaff, W.; Western Esotericism: $A$ Guide for the Perplexed, Bloomsbury Academic: London, 2013.

20. History of the doctrine of the chemical process. Universal history of chemistry, Nauka: Moscow, 1981.

21. Jung, $\square$. G.; $\square$ dler, G.; Jaffé, $\square$;; Hull, R. F.; Letters, Routledge: London, 1990.

22. Jung, C. G.; Alchemical studies, Princeton University Press: Princeton, NY, 1990.

23. Jung, C. G.; Psychology and Alchemy, Princeton University Press: USA, 1980.

24. Kabanov, V. A.; Petrov, R. V.; Khaitov, R. M.; A new principle of synthetic immunogen creation; Zhurnal Vsesoyuznogo Khimicheskogo Obshchestva 1982, 27, 57.

25. Khotynsky, M. S.; Witchcraft and mysterious phenomena in modern times, Glazunov: St.Petersburg, 1866.

26. Kokhnovich, M. A.; Gribencha, S. V.; Mukhin, A. N.; Seliverstov, A.; Verkhovskiy, O. A.; Nepoklonova, I. V.; Aliper, T. I.; Estimation of different adjuvants' influence on antigenic activity of rabies vaccine for small domestic animals; Materials of the 18th Moscow International Veterinary Congress on Diseases of Small Domestic Animals, Moscow 2010.

27. Kraig, D. M.; Modern magic: Twelve lessons in the high magical arts, Llewellyn Publications: St. Paul, MN, 2011.

28. Kravchenko, I. N.; Khokhlova, O. N.; Kravchenko, N. N.; Puzhalin, A. N.; Diachenko, I. A.; Murashev, A. N.; Hematological indices of free from pathological flora rats CD (Sprague Dawley) and mice CD1 n; Biomeditsina 2008, 2, 20.

29. Magomedov, M. M.; Bedirhanov, N. V.; Gimbatova, T. M.; Burying people ... alive and ... in millions, CSI, Avitsenna: Mahachkala, 2009.

30. Maier, M.; Runaway Atalanta, or New Chemical Emblems that reveal the Mysteries of Nature, Enigma: Moscow, 2004.

31. Mathers, D.; Alchemy and psychotherapy: Post-Jungian perspectives, Routledge: London, 2014.

32. Nosachev, P. G.; Renegade knowledge: The study of marginal religiosity in the $X X$ and the beginning of the XXI century: historical and analytical study, OSTGU: Moscow, 2015.

33. O'Hagan, Derek, T.; MF59 is a safe and potent vaccine adjuvant that enhances protection against influenza virus infection; Expert Review of Vaccines 2007, 6(5), 699.

34. Paracelsus; Labirintus medicorum errantium, Stuttgart: Philipp Reclam jun. 1993, 35. 
35. Petrov, R. V.; Kabanov, V. A.; Khaitov, R. M.; Immunology 1986, 1, 5.

36. Petrov, R. V.; Khaitov, R. M.; Ataullakhanov, R. I.; Immunogenetics and synthetic antigens, Meditsina: Moscow, 1983.

37. Petrov, R. V.; Khaitov, R. M.; Ataullakhanov, R. I.; Molecular mechanisms of activation by oxitovpolyions. 1. Modification of transmembrane transport of cations; Biologicheskiye Membrany 1984, 1(8), 599.

38. Petrov, R. V.; Khaitov, R. M.; Immune response to synthetic antigens; Dostizheniya Sovremennoi Biologii 1979, 88(6), 307.

39. Plato; Phaedrus, Progress: Moscow, 1989.

40. Regardie, I.; Cicero, C.; Cicero, S. T.; The tree of life: An illustrated study in magic, Llewellyn Publications: Woodbury, Minn., 2010.

41. Ruska, J. Tabula smaragdina ein Beitrag zur Geschichte der hermetischen Literatur, Carl Winters Universitätbuchhandlung: Heidelberg, 1926.

42. Savina, S. V.; Ivashchenko, S. V.; Skornyakov, V. M.; Murtaeva, V. S.; The effect of synthetic adjuvant on the formation of the immune response; International research journal 2016, 82(50), 42.

43. Savina, S. V.; Skornyakov, V. M.; Chastov, A. A.; Veselovsky, S. Yu.; Evaluation of reactogenic properties of chemical polyelectrolyte substanceadjuvant in experiment; International research journal 2017, 5-2(59), 1; Guénon, R.; Symbols of Sacred Science, Sophia Perennis: Hillsdale, NY, 2004.

44. Smirnova, I.; Mysteries of Magic, Veche: Moscow, 2004.

45. Stuckrad, Kocku von; Locations of Knowledge in Medieval and Early Modern Europe: Esoteric Discourse and Western Identities, Brill: Leiden, 2010.

46. Wasserstrom, S.; Religion after Religion: Gershom Scholem, Mircea Eliade, and
Henri Corbin at Eranos, Princeton UP: Princeton, 1999.

47. Weidner, J.; Bridges, V.; Weidner, J.; The mysteries of the great cross of Hendaye: Alchemy and the end of time, Destiny Books: Rochester, VT, 2003.

48. Wittgenstein, L.; Anscombe, G.; Rhees, R.; Wright, G.; Bemerkungen über die Grundlagen der Mathematik, Suhrkamp: Frankfurt am Main, 1974. 